\title{
Organizational Creativity and IT-based Support
}

\author{
Celina M. Olszak \\ University of Economics in \\ Katowice, Poland
}

\author{
Jerzy Kisielnicki \\ Warsaw University, \\ Poland
}

\section{celina.olszak@ue.katowice.pl}

\begin{abstract}
The main aim of this paper is to provide a theoretically and empirically grounded discussion on IT-based organizational creativity support. This study attempts to answer the following questions: (1) what is the issue of organizational creativity and its IT-based support, (2) what is the demand for IT -based organizational creativity support; (3) what are the main determinants and barriers to IT-based organizational creativity support; and (4) what success factors are crucial for IT-based organizational creativity support. This paper presents the analysis results of a survey conducted in 25 selected organizations.

The paper provides valuable information on the possibilities of IT applications in organizational creativity support as well as the associated success factors. It makes useful contribution to our better understanding of IT-based organizational creativity support issues.
\end{abstract}

Keywords: Organizational creativity, IT-based organizational creativity support, success factors

\section{Introduction}

Although studies on creativity have been developing for three decades, they have not addressed the essence of organizational creativity and its IT-based support. They have been mainly focused on creative problem solving, creative processes and individual creativity support systems (Cooper, 2000; Dewett, 2003). The issue of IT-based organizational creativity support is still insufficiently investigated. The research studies are fragmented and scattered.

Organizational creativity is considered one of the most actively developing research areas. It is asserted that it is a main vehicle of organizational development, the basis for staying in the market and innovative success (Amabile, 1988; Elsbach \& Hargadon, 2006; McLean, 2009; Shin \& Zhou, 2007). Organizations face the need to constantly generate new and useful ideas that concern products, services, processes, managerial practices as well as competitive strategies. Effec-

Material published as part of this publication, either on-line or in print, is copyrighted by the Informing Science Institute. Permission to make digital or paper copy of part or all of these works for personal or classroom use is granted without fee provided that the copies are not made or distributed for profit or commercial advantage AND that copies 1) bear this notice in full and 2) give the full citation on the first page. It is permissible to abstract these works so long as credit is given. To copy in all other cases or to republish or to post on a server or to redistribute to lists requires specific permission and payment of a fee. Contact

Publisher@InformingScience.org to request redistribution permission. tive support of acquiring, collecting, storing and analyzing different information resources as well as discovering new knowledge and its rapid dissemination are of crucial importance (Arora \& Nandkumar, 2012; Sirmon, Hitt, Ireland, \& Gilbert, 2011; Zahra, Sapienza, \& Davidsson, 2006). Several arguments can be found in the pertinent literature that Information Technologies (IT) enables organizations faster and easier access to information, improving creativity in business process- 
es, and better communication between employees and all stakeholders (Cooper, 2000; Davenport, 2013). IT enables an organization to search and absorb new knowledge that is needed in organizational creativity and solving business problems. On the other hand, the praxis shows that success from IT-based creativity support is still questionable. Many organizations are not able to make IT an effective tool for creativity support. The reasons for this failure are not clear and still not well investigated. The need for a more systematic and deliberate study of creativity support for organizations is crucial.

The main task of this paper is to provide a discussion on organizational creativity and its IT-based support. This discussion enables us to answer the following questions: (1) what is/are the issue(s) of organizational creativity and its IT-based support, (2) what is the demand on IT -based organizational creativity support; (3) what are the main determinants and barriers to IT-based organizational creativity support; and (4) what success factors are crucial in IT-based organizational creativity support. The search for answers to these questions is mainly conducted on theoretical and empirical foundations. At the start, a critical review of the relevant literature is conducted to identify the organizational creativity issue and its computer support. The search for the appropriate literature begins with different bibliographic databases, e.g., EBESCOhost, Emerald Management 75 , ISI Web of Knowledge, ProQuest, and Scopus. Additionally, the open access papers are explored. Then, the results of the survey conducted in 25 purposefully selected organizations are presented. In-depth interviews as well as critical thinking and inductive inference are used to consider the collected data. Finally, the theoretical contributions, practical implications, and future directions of the study are presented and discussed.

\section{Theoretical Background}

\section{A Need for Organizational Creativity}

The concept of creativity has been widely discussed in various disciplines including psychology, sociology, organizational behaviors and information systems (Amabile, 1983; Cooper, 2000; Khedhaouria \& Belbaly 2011; Styhre \& Sundgren, 2005; Woodman, Sawyer, \& Griffin, 1993). It is therefore not surprising that the term of "creativity" is explained very differently as shown in Table 1. One of the most citied definitions of creativity says that the outcomes of creativity are ideas that are distinguished by novelty and usability (Amabile, 1983; Kao, 1989). Many authors highlight that these ideas are used to achieve some particular aims and that they have a significant impact on an organization (Arieli \& Sagiv, 2011; Puccio, Mance, \& Murdoch, 2011).

Some authors advocate that creativity means creating something new that is based on exploring different information resources (data bases and knowledge bases) (Baron, 2012). Creativity is compared to knowledge systems (Basadur, Basadur, \& Licina, 2012) used for solving different problems and increasing organizational effectiveness (Houghton \& DiLiello, 2010). It is highlighted that creativity is crucial in solving semi-structured or un-structured problems (Mumford, Medeiros \& Partlow, 2012)

Although the term "creativity" is rooted in psychology, it is used in different organizational contexts - business strategy, business processes, strategic management, competitive advantage, organizational development, leadership and innovation (Bessant \&Tidd, 2011; Drucker, 2014). According to many scholars (Choi, Madjar \& Yun, 2010; Gong, Huang \& Farh, 2009; Klijn \& Tomic, 2010; Zhou \& Ren, 2012) "organizational creativity" means the capability to generate new and useful ideas that concern products, services, processes, managerial practices as well as competitive strategies. It is treated as a main vehicle of organizational development (Elsbach \& Hargadon, 2006), the basis for staying in the market and innovative success (Klijn \& Tomic, 2010; McLean, 2009; Shin \& Zhou, 2007) (See Figure 1.) 
Table 1. Interpretation of creativity term.

\begin{tabular}{|c|c|}
\hline Description & Authors \\
\hline \multicolumn{2}{|c|}{ Generation of new ideas, structures, services and processes } \\
\hline Creation of new and useful ideas & $\begin{array}{l}\text { (Amabile, 1983; Amabile, 1996; Unsworth, 2001; } \\
\text { Alge, Ballinger, Tangirala, \& Oakley, 2006; } \\
\text { Gong, Huang, \& Farh, 2009; Kim, 2010) }\end{array}$ \\
\hline Generation of new structures and artifacts & (Boden, 2009) \\
\hline $\begin{array}{l}\text { Generation of new and useful ideas that concerns } \\
\text { products, services, managerial practices, business } \\
\text { models and competitive strategies }\end{array}$ & (Zhou \& Ren 2012) \\
\hline \multicolumn{2}{|c|}{ Interaction } \\
\hline $\begin{array}{l}\text { Interaction between the talents, the process and the } \\
\text { environment, through which a visible, new and } \\
\text { useful product is created }\end{array}$ & (Plucker \& Makel, 2010) \\
\hline \multicolumn{2}{|c|}{ Process } \\
\hline $\begin{array}{l}\text { Process that is manifested in a new, useful product } \\
\text { accepted by the social context } \\
\text { Higher-order cognitive process }\end{array}$ & $\begin{array}{l}\text { (Mainemelis, 2010) } \\
\text { (Arieli \& Sagiv, 2011) }\end{array}$ \\
\hline \multicolumn{2}{|c|}{ New behaviors and interpretations } \\
\hline $\begin{array}{l}\text { Organizational creativity is essential for the crea- } \\
\text { tion of new behaviors and interpretation in unex- } \\
\text { pected situations that are difficult to plan and pre- } \\
\text { dict }\end{array}$ & (Bechky \& Okhuysen, 2011) \\
\hline \multicolumn{2}{|c|}{ Organizational capability } \\
\hline $\begin{array}{l}\text { Capability of organization to create new and useful } \\
\text { ideas }\end{array}$ & (Mumford, Robledo, \& Hester, 2011) \\
\hline $\begin{array}{l}\text { Possible source of organizational effectiveness and } \\
\text { a source of competitive advantage }\end{array}$ & (Amabile, 1988) \\
\hline $\begin{array}{l}\text { Dynamic capabilities of organization meaning the } \\
\text { acquiring of new resources and creation from them } \\
\text { the new configurations }\end{array}$ & (Sirmon et al., 2011) \\
\hline \multicolumn{2}{|c|}{ Knowledge System } \\
\hline $\begin{array}{l}\text { Creation something new from existing information } \\
\text { and knowledge }\end{array}$ & (Baron, 2012) \\
\hline $\begin{array}{l}\text { System of knowledge, processes and skills needed } \\
\text { in workflow }\end{array}$ & (Basadur, Basadur, \& Licina, 2012) \\
\hline \multicolumn{2}{|c|}{ Sum of different functions } \\
\hline $\begin{array}{l}\text { Creativity as a sum of following functions: the } \\
\text { creative person, creative task, organizational con- } \\
\text { text (culture) }\end{array}$ & (Sundgren \& Styhre, 2007) \\
\hline
\end{tabular}


Tool

Key strategic tool that allows to take the competitive advantage

(McLean, 2009)

(Mclean, 2009$)$

It is said that organizations that support organizational creativity and adopt innovative practices, products, and services increase their capability to be more competitive (Drazin, Glynn, \& Kazanjian, 1999; Mumford et al, 2011; Parjanen, 2012). Creativity is important, not only for long-term survival of the organization and the struggle with unexpected organizational situations (Robinson \& Stern, 1997), but also for the whole social-economic development (Florida, 2002).

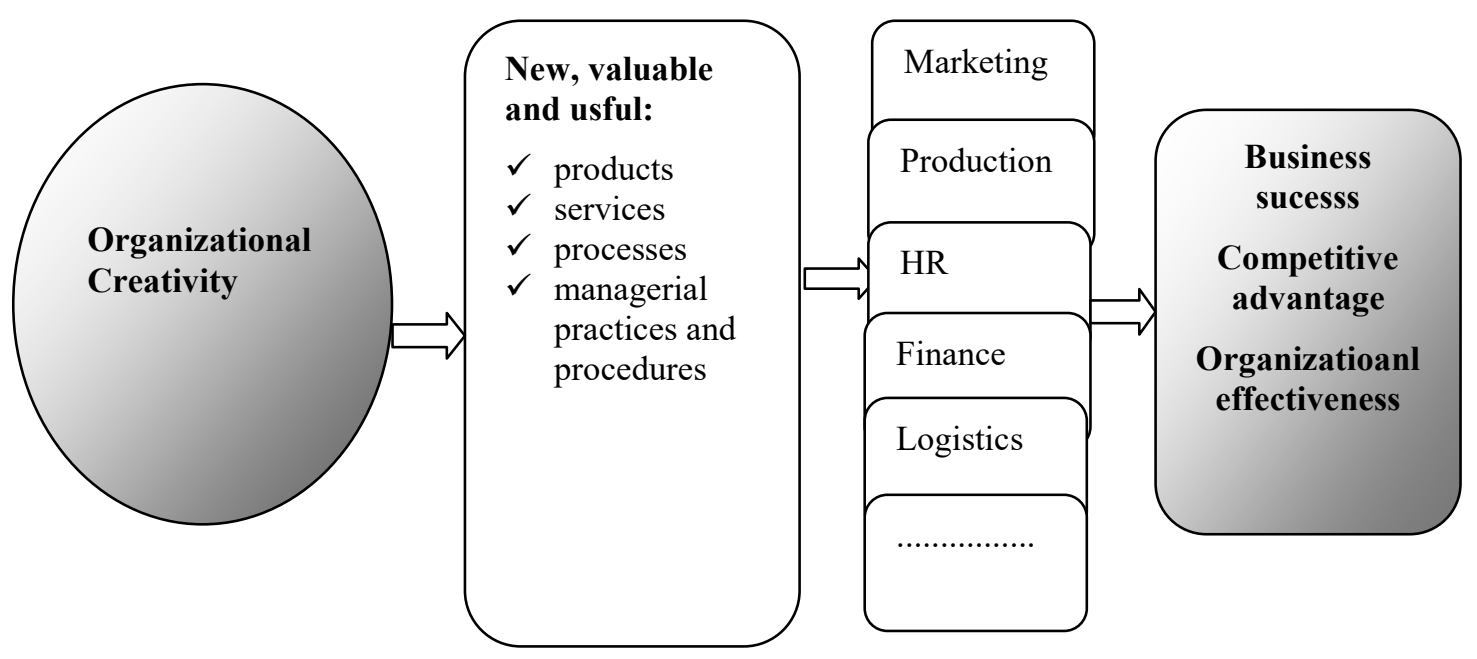

Figure 1: Organizatioanl creativity a vehicle of organizatioanl development

With regards to exploring the creativity issue, it is worth mentioning that creativity may be described from a static or process view. From this first view (static), it means a discrete task accomplished by individuals or small groups that are isolated from the organizational context, environmental factors, interactions in business processes and workflow (Borghini, 2005; Drazin et al., 1999). In contrast, process view is focused on business processes, managerial practices, and work processes (Borghini, 2005; Ford, 1996). It describes how people and IT influence each other and how creativity may be developed on different organizational levels (Hall \& Johnson, 2009).

Many studies on creativity issues have been focused on individuals, groups, and organizations as the level of analysis (Csikszentmihalyi \& Sawyer, 2014). Existent theories explain the occurrence of creativity, creative behavior, and creative products at these levels. According to von Brocke, Seidel, and Simons (2010), individual features, cognitive possibilities, motivation, and knowledge have been identified as factors that impact on the creative outcome. At the group level, factors such as leadership, group composition, group structure, cohesiveness, and availability of resources have been proposed. While at the organizational level, the most important factors that have a strong effect on creativity include organizational climate, organizational culture, leadership style, structure, and systems as well as making risky subjects and legitimacy conflicts.

Woodman et al. (1993) define organizational creativity as the creation of a valuable, useful new product, service, idea, procedure, or process by individuals working together in a complex social system. New ideas must constitute an appropriate response to fill a gap in production, marketing or the administrative processes of the organization (Parjanen, 2012). Therefore, creativity could 
be seen as an important organizational capability (Amabile, 1988), a possible source of organizational effectiveness and a source of competitive advantage. It is a collaborative psychological process that takes place in an organization and is affected by contextual and organizational factors (Blomberg, 2014). According to Brennan and Dooley (2005) creativity within an organizational context can be regarded as the sum of the following functions: the creative person, creative task, and the organizational context (culture). Sundgren and Styhre (2007) note that organizational creativity is something more than a collection of creative individuals. Thus, the mere presence of creative individuals in an organization does not guarantee organizational creativity, since it is the result of the whole spectrum of organizational factors. Amabile, Schatzela, Monetaa, \& Kramer (2004) pointed out that the extent to which people produce creative ideas depends not only on their individual characteristics, but also on the work environment that they perceive around them. Styhre and Sundgren (2007) claim that a crucial role in supporting and enhancing organizational creativity is played by managers and leaders. They must adopt styles that are unique and based on agility, perceptiveness, and rapid decision-making. Stenmark (2005) argues that the most important factors enhancing organizational creativity include motivation (quality of work, financial rewards, challenging goals, accountability, job satisfaction), autonomy (influence on work, job control, self-managed teams, absence of external control), work setting (supportive evaluation, collaborative flow, job complexity, cognitive diversity, structured interaction), climate (attitudes towards change, risk talking, management support, supportive environment, management style), and additional aspects (work load, slack, time to experiment, cognitive style, creative style).

Rosa, Qualls, and Fuentes (2008) identified four management principles that can engender creativity and innovation in organizations: (1) to manage organizations so that their knowledge base is more diverse than what would occur naturally; (2) to encourage employees to embrace a collaborative and non-complacent attitude towards work and the organization; (3) to make it possible for organization members to engage in the quick testing of ideas and solutions as they emerge; (4) to reward employees and supervisors' behaviors that support the principles and punish resistance to their implementation. To the contrary, some authors specified some barriers to organizational creativity. They include intolerance of differences, overly rational thinking, inappropriate incentives and excessive bureaucracy (Brennan \& Dooley, 2005).

Many authors point to a link between creativity and innovation. Baer (2012) states that creativity can be viewed as the first stage of an innovation process. Creativity is the starting point for any innovation. However, creativity is an individual and solitary process and innovation is a more inclusive process involving many people. Brennan and Dooley (2005) indicate that ability to stimulate innovation is highly dependent upon the stock of potential ideas and problem solving that are products of an organization's creativity processes. In order to promote innovation as an output of creativity, the organization must itself be creative and imbibe a culture of innovativeness (Sirkova, Ali Taha, Ferencova, \& Safarik, 2014).

The analysis of the relevant literature allows us to state that there is not a comprehensive view on organizational creativity.

\section{Link between IT and Organizational Creativity}

Information Technology has become crucial for organizational success and has been the focus of a significant amount of recent organizational literature (Dewett, 2003; Olszak, 2016; Olszak \& Bartuś, 2013). However, to date there has been little research aimed at IT-based organizational creativity support.

Woodman et al. (1993) point out that IT tools in the context of organizational creativity should enable, first of all, information flow and communication in an organization. In turn, Dewett (2003) claims that three benefits appear to be particularly salient: the improved ability to link and 
enable employees, the improved ability to codify the organization's knowledge base, and improved boundary spanning capabilities. Heweet et al. (2005) postulate that IT should enable brainstorming process, recombination of ideas, ranging of ideas according to different criteria, and identification of interdependences. Lubart (2005) highlights the importance of "what-if" analyses, data and processes visualization, creative process' effects dissemination, visualization of ideas, human-computer dialogue in the problem solving process. Greene (2002) states that organizational creativity support software should be able to explore problem domain, teach and discover new problems, support collaboration, visualize domain interdependences as well as to simplify storing, classifying and mining of notions. Ulrich and Mengiste (2014) highlight the importance of advanced human-computer interaction, business plan support, and storing of users' preferences. Shneiderman (2007) argues that IT tools should:

- offer indexes for work progress measurement, together with the possibility of generating alerts;

- contain libraries of images, thesauri, sketching interfaces, possibility of ideas mapping;

- support communication and collaboration, enable group work coordination;

- simplify knowledge coding in an electronic form.

According to Davies et al. (2013), creativity support systems (CSS) refer to fuzzily defined domains, having unknown requirements, with fuzzily defined measures of success, and are intended to support not precisely defined users, or their users behave in an unconventional way.

Shneiderman (2007) states that technologies that "enable people to be more creative more often" are referred to as creativity support systems. Technically, the term CSS concerns a class of information systems encompassing diverse types of IS that share the enhancement of creativity. CSS may be used to (1) enhance a user's ability to perform creative tasks (the ability that the user possesses already), (2) support users in domain knowledge acquisition, in order to free up their creativity, and (3) give users new experiences concerning creative tasks, thus giving them new tasksolving capabilities (Nakakoji, 2006). Indurkhya (2013) claims that CSS stimulate users' imagination, the creation of new ideas, and model creative processes. Muller and Ulrich (2013) as well as Klijn \&Tomic (2010) argue that CSS may be used for:

- information collecting - by simplification of searching, browsing, and visualization,

- defining linkages between information;

- creative processes - by loose associations, examination of solutions, composing of artifacts, idea reviewing;

- disseminating the effects of creative cooperation.

Some authors distinguish between three types of CSS (Nunamaker, Briggs, \& Mittleman, 1996; Voigt, Niehaves, \& Becker, 2012): individual creativity support systems (ICSS), group creativity support systems (GCSS), and organizational creativity support systems (OCSS). The main purpose of ICSS is to increase the cognitive process, individual inspiration, as well as the learning and reasoning of individual persons. The most popular tools used in ICSS include editors, visualization systems, brainstorming, e-mails, spreadsheets, databases and knowledge bases, scenarios, and modeling tools. In turn, GCSS encompass several types of information systems, e.g., group decision support systems, knowledge management systems, computer-mediated communication, which commonly support the process of idea generation and idea evolution, and selection in groups. GCSS combines the properties of individual creativity support with collaboration and coordination support. OCSS opens a new emerging group of creativity support (Olszak \& Bartuś, 2015). In contrast to previous systems, OCSS is dedicated to the whole organization and its environment. Its purpose is to increase competitive advantage and an organization's performance by offering rapid access to different, heterogeneous, dispersed information resources, their analysis, 
knowledge discovery, its visualization, and suggesting some opinions that may be the foundation for the creation of new and useful ideas.

Figure 2 presents the most important functions of IT in organizational creativity support that are quoted in the literature (Davenport, 2013; Drews, Morisse, \& Zimmermann, 2013; Heweet et al., 2005; Klijn \&Tomic, 2010; Luftman, 2015; Shneiderman, 2007; Ulrich \& Mengiste, 2014).

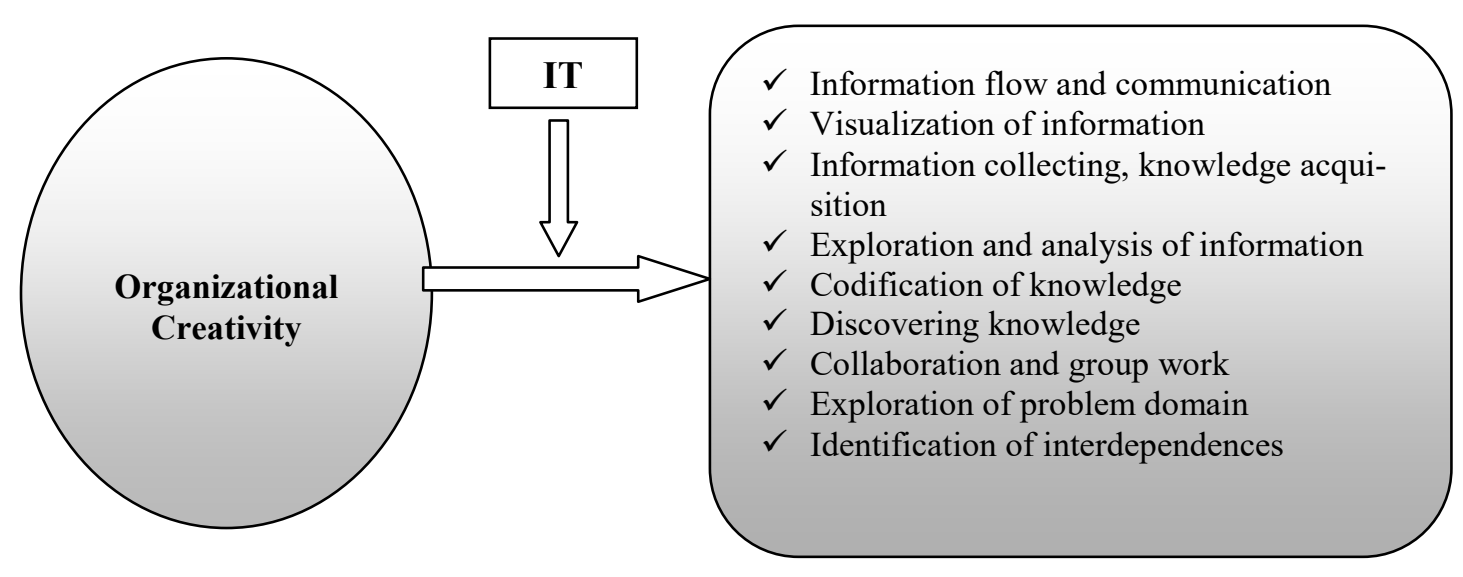

Figure 2: IT in organizational creativity support. Research Method

The main objective of this study is to identify the issue of IT-based organizational creativity support. Attaining it was connected with a partial implementation of three objectives, namely:

- To determe the demand for organizational creativity and its IT-based support;

- To identify the determinants and barriers to IT-based organizational creativity support;

- To identify the success factors for IT-based organizational creativity support.

To address these aims, a critical analysis of the literature, in-depth interviews as well as critical thinking and inductive inference were used (Table 2).

Table 2: Research methods.

\begin{tabular}{|c|c|c|c|}
\hline Purpose of Research & Research Method & Results & Research group \\
\hline $\begin{array}{l}\text { Determining the de- } \\
\text { mand for organizational } \\
\text { creativity and its IT- } \\
\text { based support }\end{array}$ & In-depth interview & $\begin{array}{l}\text { List the most require- } \\
\text { ments for IT-based } \\
\text { organizational creativi- } \\
\text { ty support }\end{array}$ & $\begin{array}{l}25 \text { purposefully selected } \\
\text { organizations }\end{array}$ \\
\hline $\begin{array}{l}\text { Identifying the deter- } \\
\text { minants and barriers to } \\
\text { IT usage in organiza- } \\
\text { tional creativity support }\end{array}$ & In-depth interview & $\begin{array}{l}\text { List the most used IT in } \\
\text { organizational creativi- } \\
\text { ty support }\end{array}$ & $\begin{array}{l}25 \text { purposefully selected } \\
\text { organizations }\end{array}$ \\
\hline $\begin{array}{l}\text { Identifying success } \\
\text { factors for the usage of } \\
\text { IT-based organizational } \\
\text { creativity support }\end{array}$ & $\begin{array}{l}\text { Critical thinking, } \\
\text { inductive reasoning, } \\
\text { In-depth interview }\end{array}$ & $\begin{array}{l}\text { List the most signifi- } \\
\text { cant success factors for } \\
\text { IT-based organizational } \\
\text { creativity support }\end{array}$ & $\begin{array}{l}25 \text { purposefully selected } \\
\text { organizations }\end{array}$ \\
\hline
\end{tabular}


The study was conducted in stages in accordance with the defined objectives. The results obtained at the individual stages of research were the basis for completion of later stages. The first stage of the study refers to an in-depth interview conducted in 25 organizations and an analysis of the demand for IT-based organizational creativity support. The obtained results showed that organizations recognize the need for use of IT-based organizational creativity support. This fact inspired us to undertake the next stage of research. This stage was to identify determinants and barriers to the use of IT-based organizational creativity support. Based on these findings, using critical thinking and inductive reasoning, the success factors for IT-based organizational creativity support were identified.

The study was conducted using in-depth interviews of individuals in 25 purposefully selected organizations that were considered to be advanced in IT and organizational creativity. The study was carried out in 2015. Sixty organizations were invited to participate in this research. Approximately $40 \%$ of invited organizations responded positively and then agreed to participate in the survey. Refusals were not justified and resulted mainly from time related constraints of individuals who were competent enough to provide valuable information. Finally, the study covered 25 selected Polish organizations. The selection of Polish organizations resulted, among others, from the fact that the Polish economy is one of the most dynamically developing economies in Europe. It is worth noting that Poland was named the "green island", as the only country in Europe not affected by the last global financial crisis. Among the surveyed organizations, 10 enterprises were from the service sector, 9 from the manufacturing sector, and 6 from the retail sector. Among the surveyed organizations, 10 represented the IT sector and telecommunications, 4 were from the construction industry, the rest were related to finance and banking, public administration, chemical sector and education. Most of the surveyed enterprises have been operating on the market for at least 5 years. The respondents were managers, directors, owners, and specialists in the field of ICT applications. All respondents declared their extensive professional experience (at least 5 years of work experience), knowledge of the issues of organizational creativity, innovation, decision support systems, and the use of IT in organizations.

The interviews were semi-structured questions addressing 26 main themes (see the Appendix). Each interview was transcribed into a word processor and spreadsheet with its data, time and codes relating mainly to the IT tools, organizational creativity activities, as well as reflective remarks. These notes were then combined with similarly coded notes covering written documents which formed a comprehensive database. The data were analyzed according to the standard methods for analysis of qualitative topics.

\section{Findings and Discussion}

\section{The Demand Diagnosis of IT-based Organizational Creativity}

This study shows that organizations are increasingly interested in creativity and innovation as new ways of gaining competitive advantage and surviving in a competitive market. The evidence is given by the feedback and comments received during the interviews with the respondents:

- "Work in our organization requires independence of thought, action, and above all creativity";

- "In order to solve the problems of our organization effectively, we have to base our activities on the principles of creativity, entrepreneurship and innovation";

- "Thanks to organizational creativity, we can create new values for customers, suppliers and other stakeholders"; 
- "Creativity is a key strategic tool that allows coping with economic adversities resulting from, e.g., various crises and economic breakdowns";

- "Creativity plays a greater role in the success than effective production systems in the new technology sectors";

- "Creativity is a key to the efficiency of our organization, trying to gain a competitive advantage and maintain it a turbulent environment";

- "Organizational creativity is a particularly valuable organizational capacity in our organization - it is the ability to create new e-services, new knowledge from existing information resources, including the use of Big Data and tacit and explicit knowledge";

- "Organizational creativity means for us nothing other than the use of modern management tools in the field of advanced analytics, artificial intelligence and modern information technology".

- "Organizational creativity means for us such activities that cause that we are one step ahead of the competition".

Most of the surveyed organizations confirmed that they are aware of the importance of organizational creativity and the role of IT in its support. They highlighted that IT allows organizations to achieve a competitive advantage, to react quickly to the changes occurring in the organization and its environment, as well as to generate new and useful ideas concerning new products and services, and to be more innovative. Additionally, they pointed out that, in order to stay on the market, the employees of organizations should perfectly know their customers, competitors, and business processes. They agreed that IT may help them to better know, e.g., customer behaviors, their preferences, and expectations.

The responders from surveyed organizations stated that IT allows them to achieve various benefits for the enterprises. It is manifested in the improvement of products and services within their organizations (22), improving innovation (18), lower costs (18), increased sales (17), shortening the delivery time of products/services to market (12) (Figure 3).

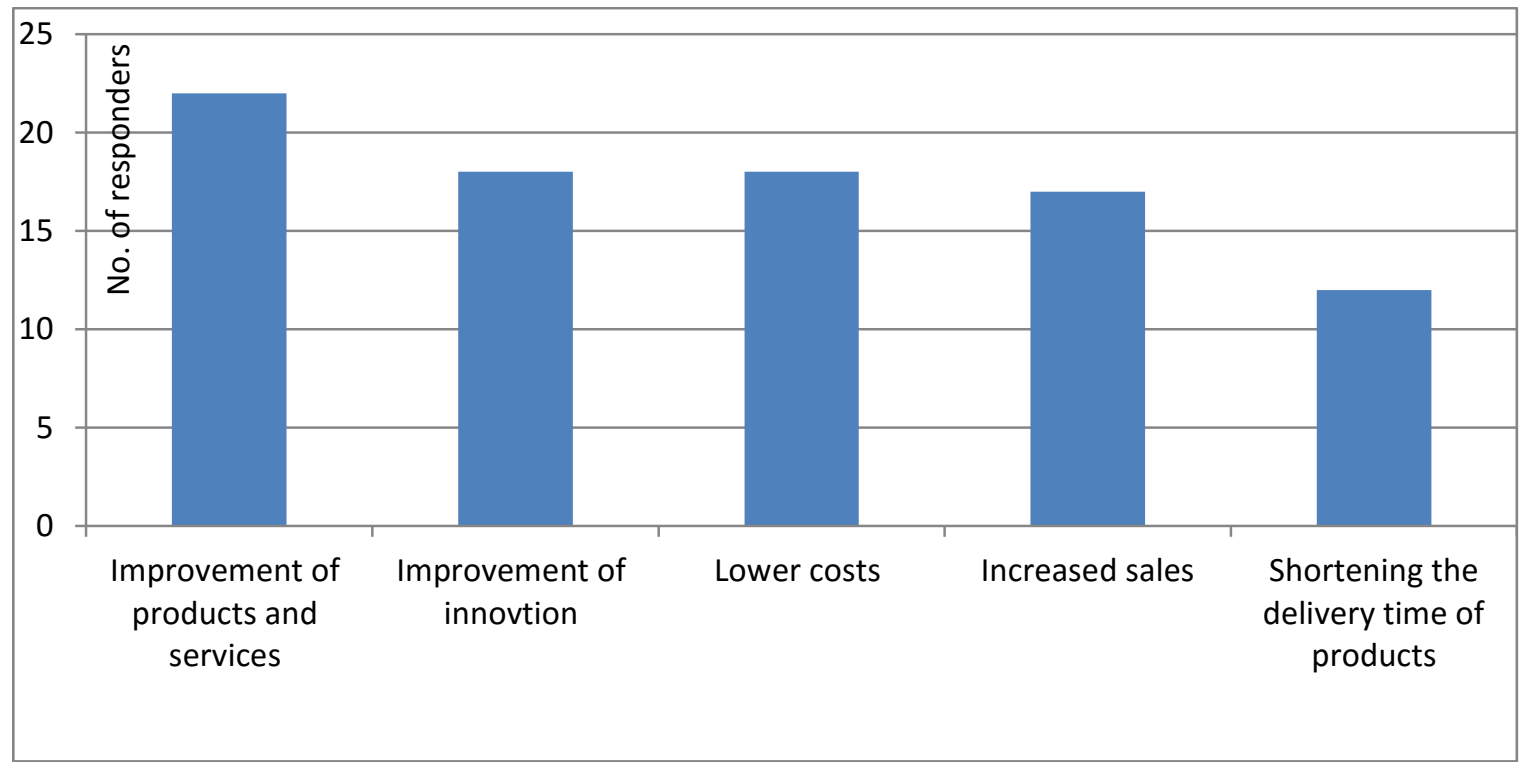

Figure 3: Perceived benefits to organizations through IT-based organizational creativity. 
It turns out that supporting organizational creativity with the use of IT in the surveyed organizations most commonly concerns such areas as HR (15 responses), Finance (14), Services (13), Logistics (13) Production (12) (Figure 4).

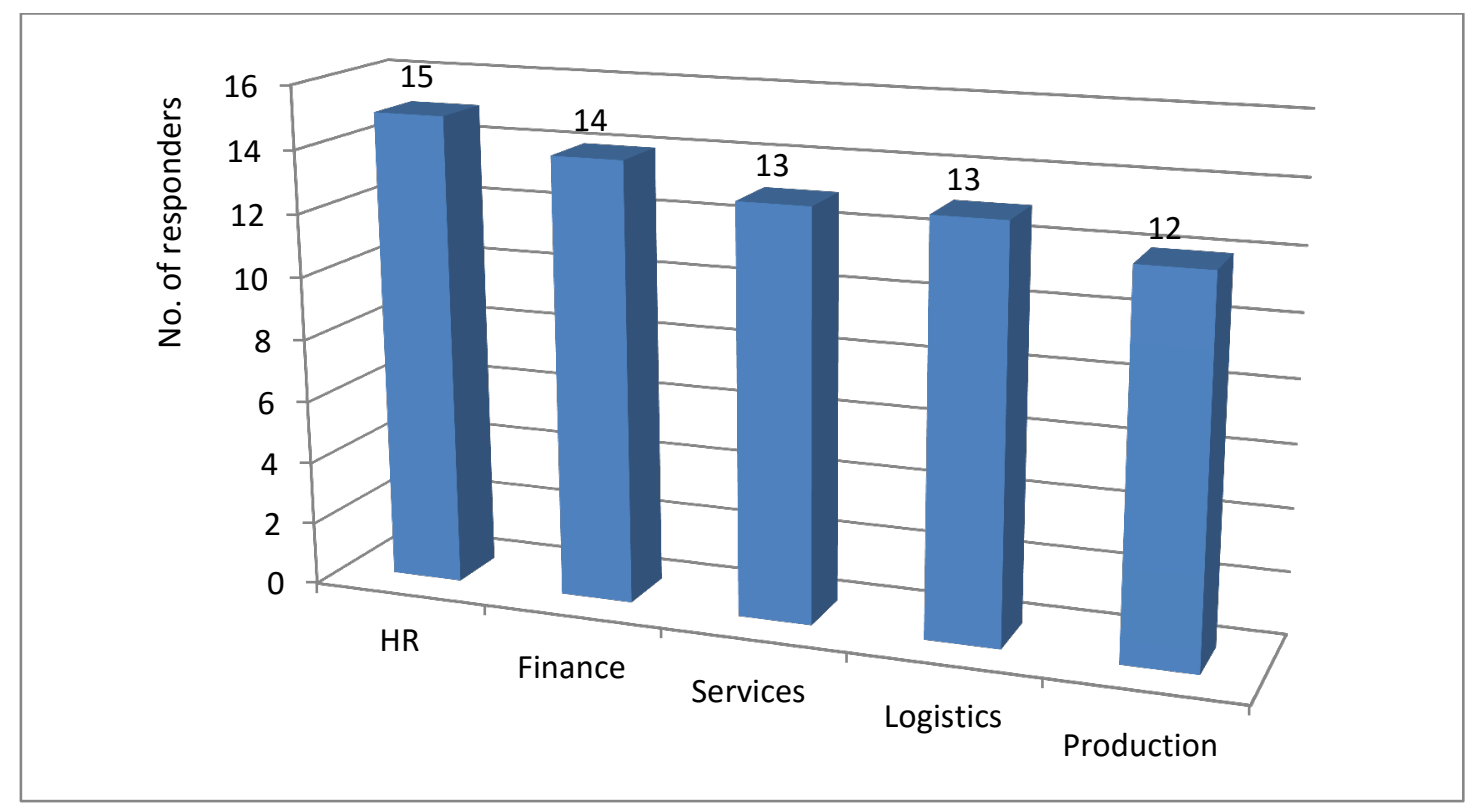

Figure 4: Areas for IT-based organizational creativity support

In the surveyed organizations, IT stimulates organizational creativity through facilitating access to various information resources (18), improving communication (18), facilitating information analysis (16), acquisition of new knowledge (13), and coding knowledge (4).

The respondents indicated that IT is used primarily in organizations to facilitate access to different databases and repositories of knowledge (21) and communication (16). Next, they pointed to the use of IT in analyzing information (10), visualization (10), teamwork (10), finding problems (9), discovering knowledge (8). Occasionally, they mentioned the use of IT in computer simulations (6), mapping knowledge (4), generalizing knowledge (3) identification of the creative needs (3), hierarchizing knowledge (1).

Among the most commonly used IT tools to support organizational creativity are (Figure 5) Internet e-mail (24), search engines (22), spreadsheets (18), databases (18), intranets (15), and data visualization tools (13 responses). The following tools were mentioned less frequently: Business Intelligence (10), extranet (10), CRM (9), groupware systems (8), expert systems (6), discussion forums (6), computer simulations (5), Big Data (5), DSS (4), CAD/CAM (4) As it can be seen, organizations use rather basic (classical) IT tools to support organizational creativity

Interesting observations arise from a series of questions about the need to be creative in the surveyed organizations. Most responders (17) considered that employees in their organizations are required to be creative, while others have expressed a neutral position on this issue. However, when asked whether the employees in their organizations are motivated to be creative, 15 respondents answered "not so decided" and the rest answered that "rather not" or that "they are not motivated to creative action at all'. The respondents pointed out a need to develop creative behaviors among organization's employees. According to their opinions creative behaviors are expected primarily from managers (18), CEO (14), employee groups (12), ICT specialists (11), individuals (10), analysts (10), and project teams (7). 


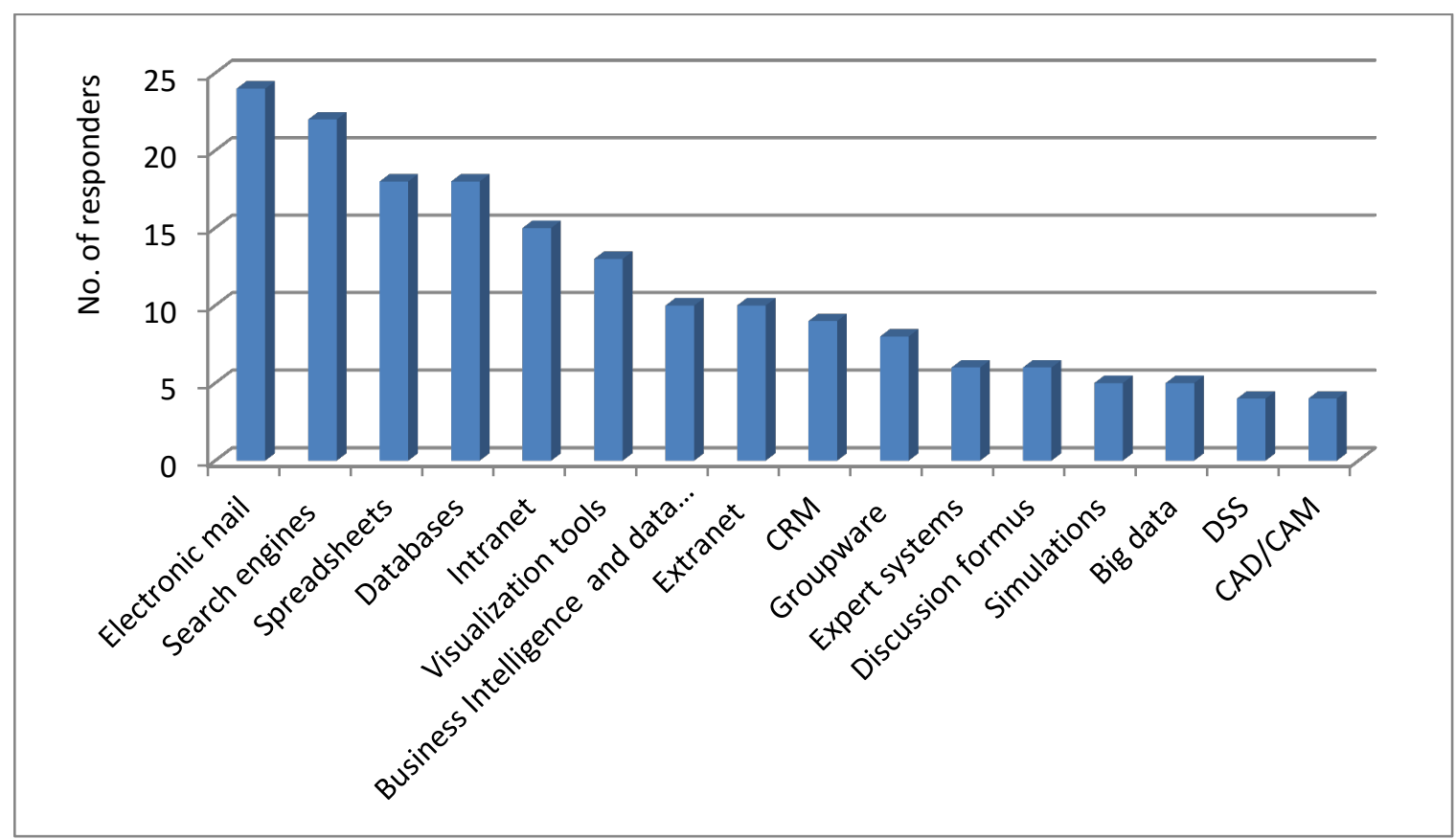

Figure 5: IT in support of organizational creativity.

From this study emerges a picture of organizations that recognize the importance of organizational creativity and IT tools for its support. They predict that IT will revolutionize management tools and be more important for the success of any organization. The surveyed organizations see the need to be creative in the activities they carry out and the need to use IT. However, this survey shows that organizations apply rather basic IT tools to support organizational creativity.

\section{Barriers to IT-Based Organizational Creativity Support}

Although all respondents underestimated the importance of IT-based organizational creativity support, nevertheless it is believed that it is often not as well developed as could be expected. Among the most frequently mentioned barriers to the development of IT-based organizational creativity support were mentioned the lack of clearly defined creative problems and needs (25), lack of adequate IT tools (23), lack of support from management (21), lack of effective communication (19), and lack of motivation for IT use (18).

From the responses emerges a rather negative image of the strategy (policy) of IT-based supporting creativity in organizations. Only two of the surveyed organizations have a coherent and clear strategy for organizational creativity and its IT-based support, in 7 organizations such a policy is run in some departments (e.g., marketing, sales), and in further 7 organizations, only some employees, individually define the creative goals and tasks (but these are rather their grassroots initiatives). In other organizations (9) strategy simply does not exist.

The employees define their preparation (knowledge) to generate new ideas with the usage of IT as rather average. Nine respondents believed that employees in their organizations are sufficiently trained to create, for example, new products and services for e-commerce, e-finance, HR (by IT). In 6 organizations, the state of knowledge and competencies of employees was far too insufficient to create original ideas. In other organizations, this state of knowledge is defined as average and probably not giving grounds for taking creative activities. 
As outlined earlier, organizations recognize the importance of organizational creativity and IT tools for its support. However, there seems to be a lack of comprehensive system solutions and management practices aimed at encouraging creativity, for both individuals and entire teams. Organizations do not carry out research on their creative needs nor do they try to understand its relationship with the organization's strategy. This raises concern that it is not entirely clear who should be responsible in organizations for the development and implementation of strategies in the field of creativity and its IT-based support. Most often this (lack of creativity self-assessment) is inherent in individual departments, which formulate their own strategies, and the selection of IT tools to support creativity can sometimes be accidental.

Some respondents emphasized that creativity and its IT-based support are not always considered desirable in organizations. The search for new ideas is sometimes considered a waste of time and money. Unconventional ideas are treated as opposing the proven ways of thinking and acting. Organizational creativity in many organizations is considered to be a change, and that, as stressed by the respondents, is associated with risk and uncertainty. Organizations are not prepared to offer employees high degree of autonomy and freedom of action. To a large extent this is due to the fact that organizations are focused on overcoming current problems and financial crises. ITbased advanced business analyses, new knowledge discovery, and exploring online resources (including social networking) do not belong to commonly performed practices. Moreover, teamwork, exchange of ideas and concepts through intranet systems are not widespread.

Often "hidden appropriation" of knowledge and unwillingness to share new ideas manifest themselves. There is a lack of professional training, developing creative skills among staff, as well as training on how to use IT to support creativity in the surveyed organizations. The respondents emphasized that they also lack the proper IT tools to efficiently acquire, collect, analyze various information as well as to discover new knowledge. It turns out that among the reasons for the use of rather basic IT tools are the lack of knowledge and skills to use more advanced IT tools (11), lack of time to learn new ITs (11), and lack of adequate tools (11).

\section{Success Factors for IT-based Organizational Creativity Support}

The knowledge, about the most important determinants of and the barriers to IT-based organizational creativity support, has become the basis for identifying the most important success factors for IT-based organizational creativity support. Critical thinking and inductive reasoning led us to indicate three categories of success factors (Table 3). They include (1) organizational culture, (2) information resources and knowledge, and (3) technology. Within the frame of an individual perspective, success factors have been identified, accounting for the different determinants and barriers. The detailed results on the identified success factors are presented in Table 3 and elaborated below. 
Table 3: Success factors for IT-based organizational creativity support.

\begin{tabular}{|l|l|l|}
\hline \multicolumn{1}{|c|}{ Organizational culture } & \multicolumn{1}{|c|}{$\begin{array}{c}\text { Information resources and } \\
\text { knowledge }\end{array}$} & \multicolumn{1}{c|}{ Technology } \\
\hline $\begin{array}{l}\text { Strategy oriented on organiza- } \\
\text { tional creativity, freedom to } \\
\text { act and agility }\end{array}$ & $\begin{array}{l}\text { Access to internal and external } \\
\text { information resources }\end{array}$ & $\begin{array}{l}\text { Adequate tools and IT infrastruc- } \\
\text { ture }\end{array}$ \\
\hline $\begin{array}{l}\text { Clear defined creative needs } \\
\text { (expectations) }\end{array}$ & $\begin{array}{l}\text { Capabilities to build various intel- } \\
\text { ligent information repositories } \\
\text { (databases, knowledge bases, data } \\
\text { warehouses, and knowledge por- } \\
\text { tals })\end{array}$ & Motivation to use IT \\
\hline $\begin{array}{l}\text { Motivation to organizational } \\
\text { creativity support }\end{array}$ & $\begin{array}{l}\text { Capabilities to discover new } \\
\text { knowledge }\end{array}$ & $\begin{array}{l}\text { Appropriate skills and compe- } \\
\text { tences to use IT }\end{array}$ \\
\hline $\begin{array}{l}\text { Support from senior manage- } \\
\text { ment }\end{array}$ & $\begin{array}{l}\text { Information quality } \\
\text { System integration and interaction } \\
\text { with other information systems }\end{array}$ \\
\hline Effective change management & Data management & $\begin{array}{l}\text { Sharing knowledge, integration of friendly IT } \\
\text { information }\end{array}$ \\
\hline
\end{tabular}

\section{An organizational culture perspective}

An organizational culture can be defined as a set of formal and informal codes of behaviors, norms, and rituals that are used and accepted within the organization. This study illustrates that the organizational culture plays a significant role in knowledge management, in decision-making as well as in organizational creativity. The obtained results show that the most important elements of an organizational culture perspective are:

- A strategic orientation of organizations on organizational creativity; most surveyed organizations highlighted the importance of setting business objectives and an ability to translate them into the language of the organizational creativity strategy. The respondents emphasized that organizational culture should be focused on flexibility, agility, creative interpersonal communication, knowledge sharing, and group work;

- Clearly defined creative needs of organizations. The responders pointed out that organizations should permanently diagnose and predict their creative needs. They should develop the skills and the capabilities in order to investigate their creative and innovative potential;

- Motivation to be creative and support from senior management. All organizations highlighted that without the support from senior management success in IT-based organizational creativity support is questionable. A system of training and motivation to undertake creative activities plays an important role.

Of relatively lesser importance regarding elements of an organizational culture, other categories were recognized: group work, communication, sharing knowledge and effective change management.

\section{Perspective of information resources and knowledge}

The obtained results show that information resources play an important role in the success of ITbased organizational creativity support. The most significant elements from an information resources perspective are: 
- An access to internal and external information resources;

- Capabilities to develop various intelligent information repositories to store up-to-date, reliable, complete and relevant information useful while looking for new ideas;

- Capabilities to discover new knowledge; and

- Information quality.

Of lesser importance, other elements that were recognized are sharing knowledge, data management, and integration of information.

The respondents highlighted that when there is no knowledge of a given topic, particular individuals must quickly assimilate relevant information and undertake an attempt to acquire the information in question. This calls for the exploration of both internal and external resources. Organizational creativity more and more frequently requires finding knowledge that stems from external resources. Such resources may include databases of patents, company reports, government records, library archives, and Internet resources including social media, blogs, comparison websites, or communities of practices. The conducted interviews indicate that organizations value highly reliable information resources and up-to-date data (internal, corporate databases - 15 responses; internal documentation - 14 responses; knowledge portals - 6 responses; specialized studies and books -6 responses). As yet, internal documents and analyses drawn up by own specialists are considered the most reliable and necessary. It is surprising to find that government databases and portals, databases of patents, and specialized portals were of minor use. The study shows that organizations most often seek information about what the competition is doing (12). Such information is necessary to improve corporate products and services. Organizations are also looking for information about the general market situation and market trends (11) and information concerning the purchasing preferences of customers on the market (9), innovations in terms of product improvement (9), as well as information about new technologies (8). One wonders, therefore, if organizations think that it helps to know what the competition is doing, or what are the buying habits of customers, then why do they make little use of resources such as social networking. It may be concluded from our interview that many organizations treat these information resources more as a curiosity, rather than as a reliable source of knowledge.

\section{Technology perspective}

Technology (software, hardware, applications, and networks) forms the foundation for organizational creativity support. It enables organizations to collect data (from different resources), convert them into information and knowledge, analyze, predict trends, create new ideas, and communicate new ideas. Consequently, the most important factors from a technology perspective were found to be appropriate IT tools, motivation to use IT, appropriate skills and competences to use IT. Of lesser importance, elements of a technology category that were recognized are system integration and interaction with other information systems, user friendly IT, and budget.

The specified perspectives of success factors for IT-based organizational creativity support were re-examined and re-assessed by the owner-managers, business analysts, and IT professionals from the surveyed organizations. It turns out that the most important elements/factors for the development of IT-based organizational creativity support, are having adequate tools and IT infrastructure (25), motivation to use IT (24), support from management (23), availability of appropriate skills (operation of IT, information analysis) (22), clearly defined problems and creative processes (21) (Figure 6). Additionally, the responders pointed out: the freedom and flexibility of action, cooperation in a group, access to appropriate tools. 


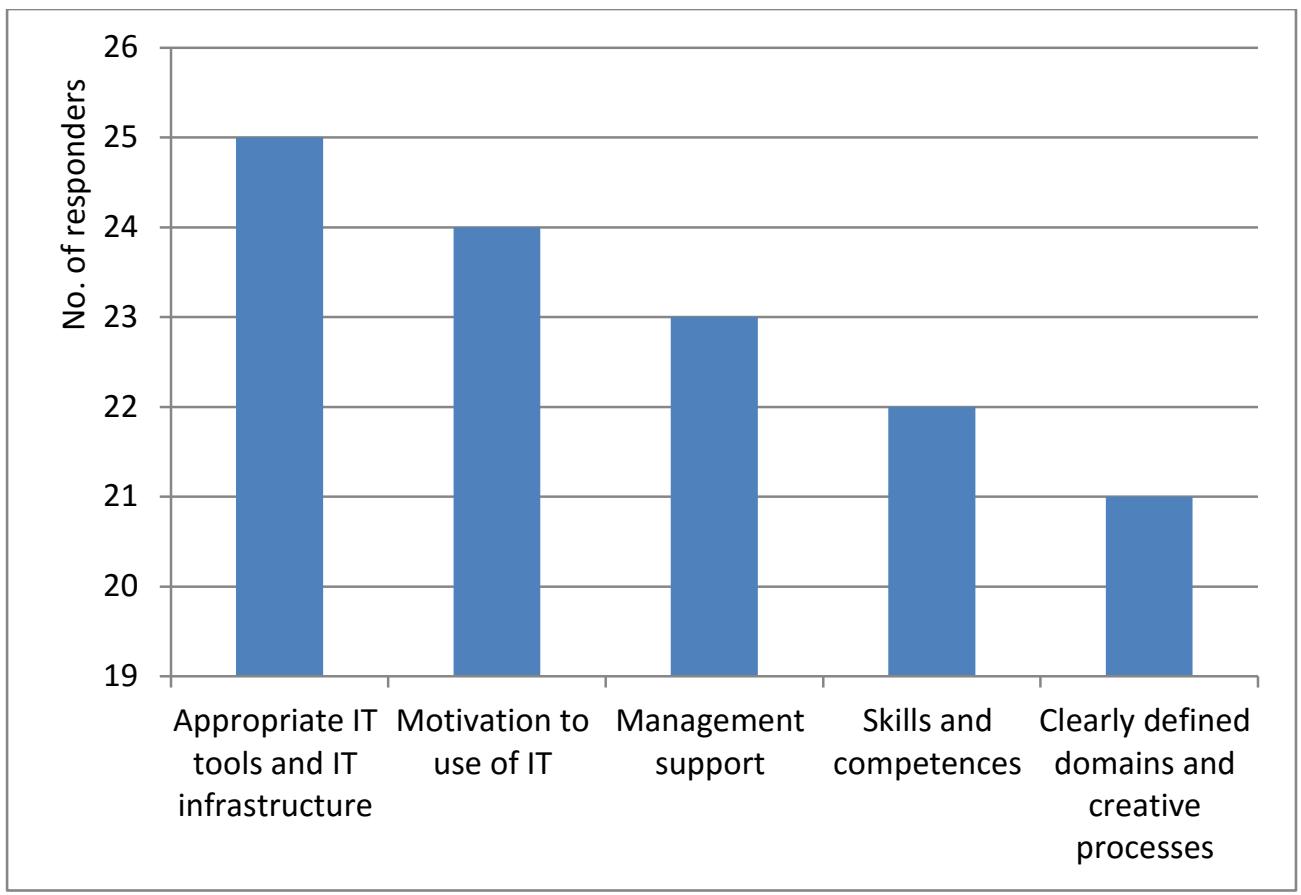

Figure 6: Success factors for development of IT-based organizational creativity.

Concluding this discussion, we note that organizational creativity and the use of IT for its support are extremely important and constitute complex research problems that require further study and analysis. It seems that the next step(s) in exploring the phenomenon of organizational creativity and its IT-based support should be quantitative tests that would cover a much greater number of organizations.

\section{Conclusions and Recommendations}

From this research emerges the subject of organizational creativity and its IT-based support as a rather poorly recognized area of research in the literature. There is little evidence (alternatively non-confirming) on the link between organizational creativity, IT, and benefits for the organizations.

The study of 25 organizations shows that most organizations use IT to facilitate access to various databases and repositories of knowledge and to improve communication. Every second or third organization pointed to the use of IT in analyzing information, visualization, teamwork, finding problems, and discovering new knowledge. Creativity in organizations and its IT-based support are mainly developed at the level of large projects and, in particular, contribute to the improvement of products and services, innovation, lowering supply costs and customer service, increased sales, and shorter delivery times of product/services onto the market.

This study has shown that, for now, none of the participating organizations have developed an overall strategy dealing with how organizational creativity can serve the creation of competitive advantage and be the means to cope in a dynamic and competitive environment. Organizational creativity is not an integral part of business strategy and the needs of creative organizations are rather poorly known. Thus, the selection of IT tools to support organizational creativity is difficult. The organizations do not have people responsible for the development of strategies in the field of organizational creativity and its IT-based support. There is no system of training and motivation to undertake creative activities. 
The study also illustrates that the most important factors for the development of IT-based organizational creativity support is concerned with having adequate tools and IT infrastructure, motivation to use IT, support from management, availability of appropriate skills, clearly defined problems, and creative processes. Additionally, the responders pointed out the necessity for the freedom and flexibility of action, cooperation in a group, and access to appropriate tools.

This study can be concluded by stressing that the development of organizational creativity and its IT-based support are important current challenges which they would have to face and deal with in the near future. In order that the organizational creativity actually becomes a driving force for the organization, they will have to create comprehensive system solutions and managerial practices aimed at encouraging and fostering creativity. The effective organizational development of creativity will require conducting reliable and in-depth research on the needs of creative organizations and their relationship with the strategy and objectives of the organization. The use of IT to assist organizational creativity will never result out of fashion, but of the necessity and benefits they both provide for organizations.

The results of this study are of practical use to scholars as well as to managers, and IT professionals who engage in the development of organizational creativity supported by using various IT tools.

\section{Acknowledgments}

This paper has been supported by a grant: "Methodology for Computer Supported Organizational Creativity" from the National Science Centre in Poland, 2013/09B/HS4/00473.

\section{References}

Alge, B. J., Ballinger, G. A., Tangirala, S., \& Oakley, J. L. (2006). Information privacy in organizations: Empowering creative and extra-role performance. Journal of Applied Psychology, 91, 221-232.

Amabile, T.M. (1983). The social psychology of creativity. New York: Springer-Verlag.

Amabile, T. M. (1988). A model of creativity and innovation in organizations. In: B. M. Staw, \& L. L. Commungs (Eds.), Research in Organizational Behavior, 10, 123-167.

Amabile, T. M. (1996). Creativity in context: Update to the social psychology of creativity. Boulder: Westview.

Amabile, T. M., Schatzela, E. A., Monetaa, G. B., \& Kramer, J. (2004). Steven leader behaviors and the work environment for creativity: Perceived leader support. The Leadership Quarterly, 15(1), 5-22.

Arieli, S., \& Sagiv, L. (2011). Culture and creativity: How culture and problem type interact in affecting problem solving. Proceedings of Academy of Management, San Antonio.

Arora, A., \& Nandkumar, A. (2012). Insecure advantage? Markets for technology and the value of resources for entrepreneurial ventures. Strategic Management Journal, 33, 231-251.

Baer, M. (2012). Putting creativity to work: The implementation of creativity ideas in organizations. Academy of Management Journal, 55(5), 1102-1119.

Baron, R. A. (2012). Entrepreneurship. An evidence-based guide. Cheltenham: Edward Elgar.

Basadur, M., Basadur, T., \& Licina, G.(2012). Organizational development. In: M. D. Mumford (Ed.), Handbook of organizational creativity (pp. 667-703). London/Waltham/San Diego: Academic Press/Elsevier.

Bechky, B. A., \& Okhuysen, G. A. (2011). Expecting the unexpected? How SWAT officers and film crews handle surprises. Academy of Management Journal, 54, 239-261. 
Bessant, J., \& Tidd, J. (2011). Innovation and entrepreneurship. New York: John Wiley \& Sons Publishing.

Blomberg, A. (2014). Organizational creativity diluted: A critical appraisal of discursive practices in academic research. Journal of Organizational Change Management, 27(6), 935-954.

Boden, M. (2009). Computers and creativity: Models and applications. In T. Rickards, M. A. Runco, \& S. Moger (Eds.), The Rutledge companion to creativity (pp. 179-188). London/New York: Routledge.

Borghini, S. (2005). Organizational creativity: Breaking equilibrium and order to innovate. Journal of Knowledge Management, 9, 19-33.

Brennan, A., \& Dooley, L. (2005). Networked creativity: A structured management framework for stimulating innovation. Technovation, 25(12), 1388-1399.

Choi, W., Madjar, N., \& Yun, Y. (2010). Perceived organizational support, goal orientation, Exchange ideology and creativity. Proceedings of Academy of Management, Montreal.

Cooper, R. B. (2000). Information technology development creativity: A case study of attempted radical change. MIS Quarterly, 24(2), 245-276.

Csikszentmihalyi, M., \& Sawyer, K. (2014). Shifting the focus from individual to organizational creativity. In M. Csikszentmihalyi, The Systems Model of Creativity (pp. 67-71). Netherlands: Springer.

Davenport, T. H. (2013). Process innovation: Reengineering work through information technology. Harvard: Harvard Business Press.

Davies, N., Zook, A., O'Neill, B., Headrick, B., Riedl, M., Grosz, A., \& Nitsche, M. (2013). Creativity support for novice digital filmmaking. Proceedings of the SIGCHI conference. New York: ACM, 651660 .

Dewett, T. (2003). Understanding the relationship between information technology and creativity in organizations. Creativity Research Journal, 15(2-3), 167-182.

Drazin, R., Glynn, M. A., \& Kazanjian, R. K. (1999). Multilevel theorizing abort creativity in organizations. A sense-making perspective. Academy of Management Review, 24, 286-307.

Drews, P., Morisse, M., \& Zimmermann, K. (2013). Towards a concept for integrating IT innovation management into business IT management. Proceedings of the Nineteenth Americas Conference on Information Systems, 1-10.

Drucker, P. (2014). Innovation and entrepreneurship. New York: Routledge.

Elsbach, K. D., \& Hargadon, A. B. (2006). Enhancing creativity through "mindless" work: A framework of work day design. Organization Science, 17, 470-483.

Florida, R. (2002). The rise of the creative class: How it's transforming work, leisure, community and everyday life. Cambridge: Basic Books.

Ford, C. M. (1996). A theory of individual creativity in multiple social domains. Academy of Management Review, 21, 1112-1132.

Gong, Y. P., Huang, J. C., \& Farh, J. L. (2009). Employee learning orientation, transformational leadership, and employee creativity: The mediating role of creative self-efficacy. Academy of Management Journal, 52, 765-778.

Greene, S. (2002). Characteristics of applications that support creativity. Communications of the ACM, $45(10), 100-104$.

Hall, J. M., \& Johnson, M. E. (2009). When should a process be art, not science? Harvard Business Review, 87, 58-65.

Heweet, T., Czerwinski, M., Terry, M., Nunamaker, J. F., Candy, L., Kules, B., \& Sylvan, E. (2005). Creativity Support Tools Evaluation Methods and Metrics. In Creativity Support Tools. A workshop spon- 
sored by the National Science Foundation, Washington. Retrieved May 2013 from http://www.cs.umd.edu.hcil/CST

Houghton, J. D., \& DiLiello, T. C. (2010). Leadership development: The key to unlocking individual creativity in organizations. Leadership \& Organization Development Journal, 11, 230-245.

Indurkhya, B. (2013). On the role of computers in creativity-support systems. In A. Skulimowski (Ed.), Looking into the future of creativity and decision support systems (pp. 233-244). Kraków: Progress \& Business Publishers.

Kao, J. J. (1989). Entrepreneurship, creativity and organization: Text, cases and readings. Englewood Cliffs: Prentice Hall.

Khedhaouria, A., \& Belbaly, N. (2011). Organizational creativity climate factors: Lessons learned from the French energy management industry. Proceedings of ECIS 2011, paper 143.

Kim, S. S. (2010). Individualism - collectivism and team creativity: A motivated information processing perspective. Proceedings of Academy of Management, Montreal.

Klijn, M., \& Tomic, W. (2010). A review of creativity within organizations from a psychological perspective, Journal of Management Development, 29, 322-343.

Lubart, T. (2005). How can computers be partners in the creative process: Classification and commentary on the special issue. International Journal of Human-Computer Studies, 63(4-5), 365-369.

Luftman, J. (2015). Influential IT management trends: An international study. Global Institute for IT Management, Fort Lee, USA.

Mainemelis, C. (2010). Stealing fire: Creative deviance in the evolution of new ideas. Academy of Management Review, 35, 558-578.

McLean, J. A. (2009). Place for creativity in management. The British Journal of Administrative Management, Autumn, 30-31.

Mumford, M. D., Medeiros, K. E., \& Partlow, P. J. (2012). Creative thinking: Processes, strategies, and knowledge. The Journal of Creative Behaviour, 46, 30-47.

Mumford, M. D., Robledo, I. C., \& Hester, K. S. (2011). Creativity, innovation, and leadership: Models and findings. In A. Bryman, D. Collinson, K. Grint, B. Jackson, \& M. Uhl-Bien (Eds.), The Sage handbook of leadership (pp. 405-421) Washington: Sage.

Muller, S. D., \& Ulrich, F. (2013). Creativity and information systems in a hypercompetitive environment: A literature review, Communications of the Association for Information Systems (CAIS), 32(1), 175201.

Nakakoji, K. (2006). Meanings of tools, support, and uses for creative design processes. CREDITS Research Center: International Design Research Symposium'06, Seoul, 156-165.

Nunamaker, J. F., Briggs, R. O., \& Mittleman, D. D. (1996). Lessons from a decade of group support system research. Proceedings of 28th Hawaii International Conference on System Sciences. IEEE Computer Society.

Olszak, C. M. (2016). Toward better understanding and use of Business Intelligence in organizations. Information Systems Management, 33(2), 105-123.

Olszak, C. M., \& Bartuś, T. (2015). Multi-agent approach in designing of organizational creativity support. In J. Q. Chen, D. Xinghua, W. Hu, \& R. Zhan (Eds.), IS management and IS engineering in the era of big data. Xi'an University of Technology: Academic Conferences and Publishing International Limited Reading UK, 93-102.

Olszak, C. M., \& Bartuś, T. (2013). Multi-Agent Framework for Social Customer Relationship Management Systems. Issues in Informing Science and Information Technology, 10, 368-387. Retrieved from http://www. iisit.org/vol10/IISITv10p367-387Olszak0055.pdf. 
Parjanen, S. (2012). Experiencing creativity in the organization: From individual creativity to collective creativity. Interdisciplinary Journal of Information, Knowledge, and Management, 7, 109-128. Retrieved from http://www.informingscience.org/Publications/1580

Plucker, J. A., \& Makel, M. C. (2010). Assessment of creativity. In J. C. Kaufman \& R. J. Sternberg (Eds.), The Cambridge handbook of creativity (pp. 48-73). Cambridge/New York: Cambridge University Press.

Puccio, G. J., Mance, M., \& Murdoch, M. C. (2011). Creative leadership. Skills that change. Thousand Oaks: Sage.

Rosa, J. A., Qualls, W. J., \& Fuentes, C. (2008). Involving mind, body, and friends: Management that engenders creativity. Journal of Business Research, 61(6), 631-639.

Robinson, A. G., \& Stern, S. (1997). Corporate creativity: How innovation and improvement actually happen. San Francisco: Berrett-Koehler.

Shneiderman, B. (2007). Creativity support tools: Accelerating discovery and innovation. Communications of the ACM, 50(12), 20-32.

Shin, S. J., \& Zhou, J. (2007). When is educational specialization heterogeneity related to creativity in research and development teams? Transformational leadership as moderator. Journal of Applied Psychology, 92, 1709-1721.

Sirkova, M., Ali Taha, V., Ferencova, M., \& Safarik, P.J. (2014). An analytical study on organizational creativity implications for management. Polish Journal of Management Studies, 10(2), 179-187.

Sirmon, D. G., Hitt, M. A., Ireland, R. D., \& Gilbert, B. A. (2011). Resource orchestration to create competitive advantage: Breadth, depth, and life cycle effects. Journal of Management, 37, 1390-1412.

Stenmark, D. (2005). Organizational creativity in context: Learning from a failing attempt to introduce ITsupport for creativity. International Journal of Technology and Human Interaction, 1(4), 80-98.

Stundgren, M., \& Styhre, A. (2007). Creativity and the fallacy of misplaced concreteness in new drug development. A white headian perspective. European Journal of Innovation Management, 10(2), 215235 .

Styhre, A., \& Sundgren, M. (2005). Managing creativity in organizations: Critique and practices. Houndmills: Palgrave Macmillan.

Ulrich, F., \& Mengiste, S. (2014). The challenges of creativity in software organizations. In B. BergvallKareborn, \& P. Nielsen (Eds.), Creating value for all through IT (pp. 16-34). Berlin Heidelberg: Springer.

Unsworth, K. (2001). Unpacking creativity. Academy of Management Review, 26, $289-297$.

Voigt, M., Niehaves, B., \& Becker, J. (2012). Towards a unified design theory for creativity support systems. In K. Peffers, M. Rothenberger, \& B. Kuechel (Eds.), DESRIST (152-173). LNCS 7286, Berlin Heidelberg: Springer-Verlag.

von Brocke, J., Seidel, S., \& Simon, A. (2010). Bridging the gap between enterprise content management and creativity: A research framework. Proceedings of the $43^{\text {rd }}$ Hawaii International Conference on System Sciences. IEEE Computer Society, 1-10.

Woodman, R. W., Sawyer, J. E., \& Griffin, R. W. (1993). Toward a theory of organizational creativity. Academy of Management Review, 18(2), 293-276.

Zahra, S. A., Sapienza, H. J., \& Davidsson, P. (2006). Entrepreneurship and dynamic capabilities: A review, model, and research agenda. Journal of Management Studies, 43, 917-955.

Zhou, J., \& Ren, R. (2012). Striving for creativity. Building positive contexts in the workplace. In K.S. Cameron \& G. M. Spreitzer (Eds.), The Oxford handbook of positive scholarship (pp. 97-109). Oxford/New York: Oxford Press. 


\section{Appendix}

\section{Semi-structured questions addressing 26 main themes:}

(1) What do you associate the term 'organizational creativity' with?.

(2) Does the work performed require from employees of your organization to be creative ?

(3) Are employees your organization motivated to be creative and break away from clichéthinking?

(4) Are employees in your organization familiar with processes, technologies and customers of your organization?

(5) In which departments/areas of your organization functioning is creativity developed or where, in your opinion, it should be developed?

(6) Does creativity translate into better functioning of the organization in your opinion and how is it expressed?

(7) At which organizational levels is creativity developed in your organization?

(8) Who is required to be creative in your organization?

(9) What hinders/kills organizational creativity in your organization?

(10) What factors do you consider as important in supporting organizational creativity?

(11) Does your organization have a strategy (e.g. objectives, tasks) in terms of organizational creativity?

(12) Do employees in your organization have sufficient knowledge, information, expertise to generate new and useful ideas for the organization?

(13) Do employees in your organization use specialized information resources in their work ?

(14) Please specify the quality of information that employees of your organization use in organizational creativity?;

(15) Which categories of information is your organization looking for in the context of organizational creativity?

(16) Is creativity in your organization supported by ICT and in which areas?

(17) Which ICT functions do you consider as important in supporting organizational creativity?

(18) Which ICT functions are used in supporting the organizational creativity in your organization?

(19) What tools are used in your organization to support organizational creativity?

(20) What makes it difficult to use ICT tools to support organizational creativity in your organization?

(21) How new ideas/concepts/new knowledge are communicated in your organization?

(22) Does your organization have a repository (common base) which stores new ideas/new knowledge?

(23) How does ICT boost creativity in your organization?

(24) What factors do you consider as important for the development of computer-aided organizational creativity?

(25) What hinders the development of IT-based organizational creativity in your opinion?

(26) Is there an R \& D department (research and development) in your organization or its equivalent (e.g. department of progress and rationalization)? 

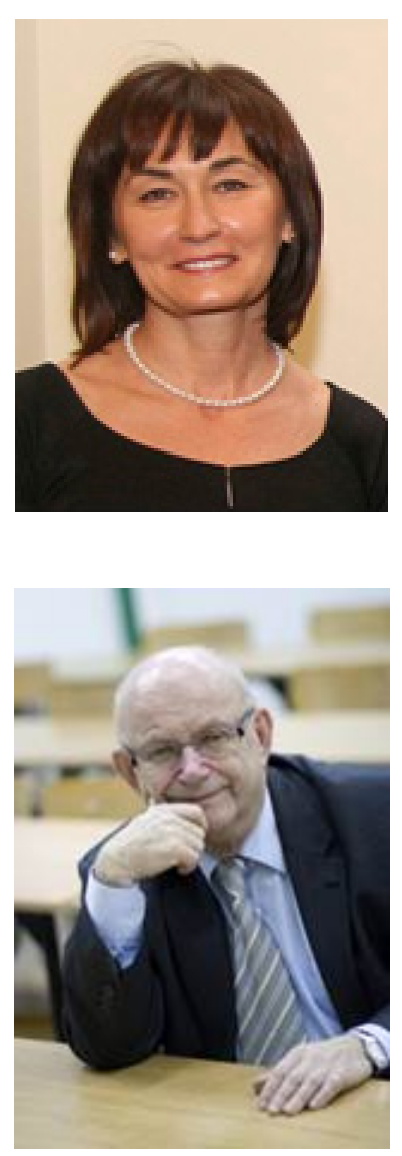

\section{Biographies}

Prof. Celina M. Olszak, Ph.D., D.Sc. is a professor of Management Information Systems at the University of Economics in Katowice, Poland. She is the chair of the Department of Business Informatics. She is also a DAAD and Swiss Government scholarship holder. She visited and took different courses at universities in Europe, the USA, and Australia. She is the author of 10 books and over 150 academic journal articles. Her research focuses on decision support systems, knowledge management, management information systems, business intelligence, big data, enterprise resource planning, and IT-based organizational creativity. She is a member of the Informing Science Institute in the USA, the PGV Network, and the Polish Academy of Sciences.

Prof. Jerzy Kisielnicki, Ph.D., D.Sc. is a professor of management, the head of the Department of Information Systems in Management and Faculty of Management at Warsaw University. His interests are organization and management, systems analysis, management information systems, e-learning, process innovation (reengineering), strategic management, and transition systems organization and management in market economy. He is a member of the Board of Organization and Management in Polish Academy of Science and the head of the Scientific Council of Polish Society of Systems Information. He is the author of about 220 publications. 